\title{
7. Whistling the dog
}

\author{
Barry Hindess
}

To rule out possible misunderstanding, I should say that I come to bury the idea of dog whistling, not to praise it. The term 'dog-whistle politics' was widely used in the 1990s and early 2000s by commentators on the Left in Australia to describe, and often to deplore, what were seen as rhetorical attempts by the Prime Minister John Howard and his supporters to appeal to anti-immigrant sentiments within the electorate, but to do so in such a way as to avoid incurring the charge of racism. It was alleged that, while the propositional content of Howard's speeches was often uncontentious, many of these speeches were designed to appeal to sections of the electorate who would respond positively to the sentiments they perceived him to be expressing. This was 'dog whistling', a matter of putting out a message that would not be noticed by many, but would be picked up by its intended audience.

I hoped that by mid-2013 the term would be of mainly historical interest, but this was too optimistic. The term resurfaced several times in the course of the year. For example, Senator Doug Cameron and Minister Peter Garrett were both reported as accusing Scott Morrison of dog whistling when he called for police and neighbours to be notified whenever refugees were released into the community (Hall 2013). A few days later, Christine Milne, leader of the Greens, accused the Prime Minister of dog whistling and Tony Abbott, without using the term 'dog whistling', accused her of 'demonising' foreign workers when she said, of 457 visas, that foreign workers should not be put at the front of the jobs queue at the expense of Australian workers. Prime Minister Julia Gillard's response to these accusations is also worth noting:

I believe in putting Australian jobs first. Others can use whatever label they choose for that. (Ireland 2013)

I will return to this exchange.

Josh Fear's useful discussion (2007) of the dog whistle in Australian politics illustrates the concept with an American example, George W. Bush's use of 'arcane - but seemingly everyday - turns of phrase derived from biblical texts in order to signal his allegiance to America's religious right' (Lincoln 2004: 5). Bush's acceptance speech at the 2004 Republican National Convention referred to 'hills to climb' and to seeing 'the valley below', an allusion to the Israelites' flight from Egypt. 
As another American example, during the 2004 campaign Bush and Dick Cheney frequently used the phrase 'He can run but he can't hide', referring to both Osama bin Laden and the Democratic presidential candidate, John Kerry. As I recall from watching broadcast coverage of that election in the Democratic bastion of Baltimore, American audiences usually greeted this statement with wild applause. At first, this reaction made no sense to me. I assumed that the phrase involved some biblical allusion with which I was happily unfamiliar, only to discover later that the phrase had been made famous by Joe Louis, a long-time world heavyweight boxing champion who, while black, was a hero of the American white working class. In repeating the 'He can run ...' phrase, Bush and Cheney were saying both that we are going to hammer him (bin Laden or Kerry) and 'I'm with you guys [i.e. white blue-collar workers]' .

In its Australian usage, 'dog whistling' is a pejorative term that relies on the image of the dog whistle, which was used in sheep herding and was also known as the 'silent' or 'Galton's' whistle, designed, apparently, by Francis Galton in 1876 to resonate at a frequency, 20,000 hertz or more, which would be inaudible to human ears but audible to the more sensitive hearing of dogs. Where humans would be generally unaffected by the sound, except for the odd headache, suitably trained or habituated dogs would receive both a sound and an instruction - telling them, for example, to stop where they were or to round up the sheep that had just broken away from the main flock - and could be trusted to respond accordingly. Dog whistlers knew what they were doing while the dogs reacted without thinking. The same term was also used, perhaps less pejoratively, in the United States and United Kingdom, where it has been labelled as Australian in origin. ${ }^{1}$

My first task in this paper is to explain what dog whistling has to do with rhetoric. At first sight this seems easy enough. Perhaps the most straightforward account of dog whistle politics is presented in Bob Goodin's Innovating democracy, which refers to:

the fundamental perversity of dog-whistle politics, whereby political parties send coded messages that will be heard one way by their core supporters and another way altogether by others. (2008: 7)

1 For the United Kingdom, see Bagehot (2005) who suggests that the practice was introduced to British politics by Lynton Crosby, the Tories' 'Australian' campaign director. Crosby developed his trade while working as federal director of the Australian Liberal Party under Howard's leadership. Crosby's responsibility for introducing the term, in a non-pejorative sense, has been suggested by J.F.O. McAllister (2005). For the United States, see William Safire (2005), who describes the dog-whistle issue as having been 'brought about possibly from Down Under - by the rise of dog-whistle politics'. Safire refers here to Peter Manning (2004) who quotes Mike Steketee of the Australian as suggesting that the term may be American in origin. A few years later Safire (2008: 190) quoted Richard Morin, director of polling for the Washington Post as writing in 1998 — well before the term was alleged to have been imported from Australia — that 'researchers use the term "Dog Whistle Effect" to refer to puzzling features of questionnaire responses: 'Respondents hear something in the question that researchers do not'. 
Later in the same book he describes dog-whistle politics as 'a new and particularly pernicious campaign technique', adding that it:

Is a way of sending a message to certain potential supporters in such a way as to make it inaudible to others whom it might alienate. The classic case, perhaps, is the 'Are you thinking what we're thinking?' campaign mounted by the Tories in the 2005 British General Election by Lynton Crosby who had perfected the technique in highly successful campaigns to re-elect John Howard in Australia. (2008: 224) ${ }^{2}$

This campaign involved one or more large political billboards located in a prominent roadside position each displaying the words 'vote Conservative'. As Martin Kettle (2005) explains, the first billboard in a sequence poses the question: 'Are you thinking what we're thinking?' A moment later, one sees a second billboard that explains: 'It's not racist to impose limits on immigration.' This last phrase, which also appeared in speeches by the party leader and in the Tory manifesto (Freeland 2005), might seem to be a statement of the obvious since, as Fear points out, all states practise some kind of immigration control (2007: 1). Yet, to its target audience, it said that you are not necessarily a racist if you oppose immigration from Africa and Asia - or, paraphrasing slightly, 'It's not seriously racist to have racist views about things that really bug you - like immigration' (Fear 2007: 1). This message can be read as a deliberate counter to the moderately effective anti-racism campaigns waged by the Left - that is, by elements within the Labour Party and the unions and by various non-Labour activist groups - campaigns that left many people nervous about expressing their (incorrect) views in public. Those in the 'Are you thinking ...' campaign's target audience knew perfectly well that they'd better not be racist. The point of the campaign was not to dispute norms promoted by anti-racism campaigns but to tell the intended audience they need not worry about them. The message of the second billboard was thus 'Labour condemns your racist views on immigration while we, in the Conservative party, understand your feelings about Asian and African immigrants. You can trust us.'

Yet, if we follow the definition offered by the Oxford English Dictionary (1989) and see rhetoric as 'The art of using language effectively so as to persuade or influence others', then we should regard dog whistling as a sophisticated kind of rhetoric, one that aims to win support from parts of an audience while also influencing, or at least, not alienating, the rest. Goodin (2008: 7) calls dog whistling perverse because it undermines democratic deliberation - try deliberating with someone who says one thing to you and, at the same time, says something different to others in the discussion - and later in the book he describes it as 'particularly pernicious' (2008: 224). He also said in an earlier

2 See Ashcroft (2010) for a sceptical Conservative assessment of this campaign. 
paper that it destroyed any sense of a democratic mandate since, if dog whistling is employed successfully, it is difficult to be sure what policies or party platform the electorate has supported (Goodin and Saward 2005). In itself, this last may not be such a bad thing.

Similar points might be made about the use of conventional rhetorical techniques. The political point of rhetoric may simply be to batter one's opponent - or to respond to their battering. In such cases, discerning listeners will know, or at least suspect, that the content of a speech should not be taken too seriously. This may be why Howard was taken by surprise in 1996 when the talk-back presenter John Laws, in his radio program (21 August), pressed him on the difference between 'core promises which are kept and then those other not so important promises, the ones we really didn't mean kind of promises'. ${ }^{3}$ Thus, recent Liberal promises to 'turn the boats around' or to 'get rid of the deficit' may not mean what they say - although some clearly fear that they do. Either way, any rhetorical speech may be accused of undermining both the practice of deliberation and the idea of a mandate. It can also give hostages to fortune, as we have seen during much of 2013 in what sounded suspiciously like a Labor promise to deliver a surplus in the current financial year.

Leaving this last complication aside, the issue of dog-whistle politics is less tidy than my earlier brief discussion suggests. First, for all the clarity of the introductory account in Goodin's book (2008: 7), it hardly captures the complexity of the term's Australian, or even American, usage, or indeed of Goodin's usage later in the same book, which declares dog-whistle politics to be 'particularly pernicious' (2008: 224). Second, there are serious problems with the idea of 'coded messages that will be heard one way by their core supporters and another way altogether by others'. I address these issues in turn on my way to the conclusion that the concept of dog-whistle politics is hardly worth the napkin it was probably first scribbled on. Those who level the accusation of dog whistling against conservative politicians certainly point to serious concerns about contemporary politics, but in an exemplary display of intellectual reflexivity, they offer what could itself be described as a clear case of dog whistling.

\section{Exploring Australian usage}

Apart from its unfortunate consequences for democratic deliberation and for claims of an electoral mandate, it might seem that the rhetorical trick of sending coded messages that mean different things to different audiences is relatively

3 Quoted at http://howardfacts.com/download/now/broken_promises_election_07.pdf, consulted 2 December 2013. 
harmless. Following this view, dog whistling is neither good nor bad, in itself, and one's assessment of the practice, as being, for example, 'particularly pernicious' (Goodin 2008: 224), would depend on the content of the coded messages that were broadcast in the public domain.

Consider just a few examples of coded messages that are not normally described as dog whistling. I begin with the widespread use of the word 'independent' in Australian public life to suggest to the public that the 'independent' whatever - Independent Commission Against Corruption (ICAC), economic modelling, environmental impact assessment, and so on - will not be affected by special interests, while those who matter will know perfectly well that economic modelling rarely bites the hand that pays it and that ICAC is funded by the NSW Government. This is dog whistling as endearingly non-partisan. Or again, consider Robert Menzies's well-known 'Forgotten people' speech delivered on 22 May 1942. This speech is usually read as an appeal to and celebration of the Australian middle class — his 'forgotten people' — but, at one point, Menzies insists on the importance of:

a fierce independence of spirit. This is the only real freedom, and it has as its corollary a brave acceptance of unclouded individual responsibility. The moment a man seeks moral and intellectual refuge in the emotions of a crowd, he ceases to be a human being and becomes a cipher.

There is room for debate about how to interpret these examples, the Australian usage of 'independent', or of 'non-partisan' for that matter, and Menzies's speech (Brett 2007). Was the speech a case of dog whistling? Did Menzies intend to suggest that labour movement activists were seeking 'refuge in the emotions of a crowd' and thus were no longer human, or was he simply carried away by his own rhetoric? Perhaps the activists were dupes of a foreign power, as Menzies's government effectively claimed in its campaign to ban the Communist Party of Australia (CPA). ${ }^{4}$

So, I move on to less contentious cases. The first is Jesus' response, reported in Matthew 22:21, to Pharisees who had tried to trick him into saying that Jews should not pay taxes to the Roman authorities. 'One of them [i.e. a Pharisee] showed him a Roman coin, and he asked them whose name and inscription were on it. They answered, "Caesar's", and he responded: "Render therefore unto Caesar the things which are Caesar's; and unto God the things that are God's".' Here, Jesus says one thing to the Pharisees, and to any Roman spies who might be listening, and something else, perhaps not entirely clear, to others who heard

4 Without stating it directly, the Australian Communist Party Dissolution Bill 1950 (Cth) presented the CPA as a threat to the defence of Australia, a view that the High Court rejected in its 1951 ruling that the Bill was unconstitutional. 
this exchange. Some of the Pharisees, one suspects, would have been smart enough to see what he was up to. Jesus has been accused of many things, but there are no reports of anyone at the time or later accusing him of dog whistling.

My second example is the infamous speech to the Roman people that Shakespeare attributes to Mark Anthony. Shortly after Caesar's death, Anthony begins:

Friends, Romans, Countrymen Lend me Your Ears. I come to bury Caesar not to praise him.

Thus far into the speech, the crowd has no clear idea of what is coming next while the conspirators relax, thinking, wrongly, that Anthony is not going to make any trouble. ${ }^{5}$ Here, too, the accusation of dog whistling has not to my knowledge been raised.

A final example comes from the realm of political theory. Readers of Leo Strauss will know that, without using the term 'dog whistle', he describes past political theorists as saying one thing to most of their contemporaries and something else, a coded message, to their informed and intelligent readers. Strauss does not condemn this practice but generally treats it as thoroughly sensible.

To these cases, we might add a final generic example, pointing out that a fundamental task of diplomacy has always been to find a form of words that would allow different parties in a dispute to believe that they had gained more than they expected.

Thus far, it seems that there is nothing new about the use of coded messages and that, in many cases, it might not be such a bad thing. Dog whistling, we might say, is problematic in roughly the way that guns are problematic: 'dog whistling does not kill people; people kill people.' Tempting as this line of argument might seem, it is important to recognise that in Australia dog whistling has generally been condemned - as it has, but rather less so, in the United Kingdom and United States - as both promoting and appealing to racist sentiments, much as Goodin condemns it towards the end of his 2008 discussion.

As Fear's invaluable discussion brings out, a central feature of the Australian understanding, which his own paper clearly reflects, is that the dog whistle is an appeal to prejudice:

5 The problem with using the Mark Anthony example here is that it is fictional. Shakespeare's theatrical version of Anthony's speech to the Roman people shortly after Caesar's assassination seems tame in comparison to the tactics said to have been urged on Marcus Cicero by his brother Quintus (Cicero 2012). There are reasons to doubt whether Quintus wrote this letter (Wills 2012) but the fact that it was circulated in Rome in the form of a letter from Quintus to his brother suggests something about the tone of Roman electoral politics, just as the decision of Princeton University Press to publish the pamphlet without noting the doubts about its authenticity suggests something unpleasant about academic publishing in contemporary America. 
many members of the community still harbour resentments based on race, religion or sexuality. And these people vote. (2007: 2)

Note the disapproving tone of the last phrase. 'And these people vote'. As if to reinforce its point, Fear suggests, further, that:

our politicians don't want to alienate members of their constituency who might be put off by blatantly prejudiced remarks. It is important that they communicate in ways that both resonate with the target audience (such as people who harbour suspicions about certain minority groups) and are inaudible to voters who hold more progressive views. Dog whistling is therefore the tactic of choice for a politician who wants to have it both ways. (2007: 2)

A little earlier (2007: 1), he describes dog whistling as 'appealing to our baser instincts'. My initial account of dog whistling, which followed Goodin (2008: 7), should therefore be amended. Accordingly, dog whistling is a practice:

whereby political parties send coded messages that will be heard one way by their core supporters and another way altogether by others.

We have seen that Goodin himself uses the example of the Tory 'Are you thinking ...' campaign to amend his account, saying that dog whistling is:

a way of sending a message to certain potential supporters in such a way as to make it inaudible to others whom it might alienate. (2008: 224)

This is much closer to capturing the Australian usage. We need only add the note of disapproval, perhaps by inserting the word 'prejudicial' immediately before 'message'. Dog whistling thus becomes a way of sending a prejudicial 'message to certain potential supporters in such a way as to make it inaudible to others whom it might alienate'. Fear emphasises this worry about alienating potential supporters by insisting that the 'key feature' of dog whistling 'is plausible deniability: the dog whistler can say "I didn't mean that, I meant this instead".' (2007: 5)

There are several issues to be noted here. One is simply that most of the discussion of dog whistling focuses on electoral competition, whereas the examples I listed earlier in this section, with the exception of Menzies's speech and his radio talks on the same theme, were not. Talk of 'independent umpires' and the like is solidly bipartisan. The key point to notice is that most of those who talk, or write, about dog whistling treat it as unfair, as a kind of cheating. Not only does it appeal to our baser motives, but there is something base about making such an appeal. I will return to a second issue - the reflexivity of the charge of dog whistling - later in this paper. 
A third issue is the question of what Max Weber calls 'value-freedom'. Weber's view (1989), which is now widely shared among social scientists, if not by those who pay for their services, is that, while our values or political commitments may well influence our choice of what topics to investigate, they have no place in the conduct of our investigation. Yet, in the case of the concept of 'dog-whistle politics', we find that the investigator's - in this case, Fear's - disapproval enters into the definition of the object of study. Goodin avoids this problem, clearly signalling his disapproval — for example, with his 'particularly pernicious' (2008: 224) — but not letting it interfere with his own conceptualisation of the phenomenon. The difficulty here is that this abstinence leaves him with no real distinction between the general phenomena of coded messaging, as in the examples listed above, and dog whistling in particular, leaving us to suspect that dog whistling should be seen not so much as a novel form of rhetoric, but rather, to borrow an image from Thomas Hobbes' Leviathan (1996: 130), as a familiar form misliked.

Fourth, we might question the use of the term 'deniability' in this context. On the one hand, deniability - an ability to deny accusations of impropriety would seem to be an attribute of those who might have something to deny, not of what they might have said. Either way, 'deniability' seems a useful enough term in the genre of practical advice to cynical politicians, but out of place as a term of serious political analysis. On the other hand, what precisely might the accused dog whistler say by way of denial?

\section{Coded messages}

Goodin describes dog whistling as a practice:

whereby political parties send coded messages that will be heard one way by their core supporters and another way altogether by others. (2008: 7)

Fear, too, divides the dog whistler's audience into those who are receptive to the prejudicial message and the rest, who fail to 'perceive (or deliberately ignore) the layered or multiple meanings':

the target audience for a dog whistle can be any group to whom politicians want to send a message without alerting others, or at least without alarming them. (2007: 2)

It seems, then, that the electorate consists of three groups:

1. those who receive and are attracted by the dog whistler's coded message 
2. those who are not sufficiently perceptive to pick up this message, and who might be offended if they did

3. the rest who pick up both the overt and the coded message, but do not care enough about the latter's prejudicial import for it to affect their political allegiances.

There is nothing in the literature to suggest that some in the first group might pick up both messages and be offended by the dog whistler's duplicity. As with two, the assumption seems to be not only that members of this group are prejudiced but also that they are not very smart. (Perhaps they failed to pay attention in their social studies classes at school.)

However one reads the charge of dog whistling, the implied description of those who respond to its call is distinctly unflattering. The image of left-wing elites who look down on the tastes and lifestyles of ordinary Australians, as Fear notes (2007: 22-25, 38-42), has long been a staple of right-wing political rhetoric, both in the United States and Australia (Sawer and Hindess 2004). This staple has been reliable because its underlying point remains hard to deny. The charge of dog whistling seems perfectly designed to reinforce this image of Left elitism.

My point here is that making the charge of dog whistling carries within itself an element of dog whistling and, in this respect, the concept is admirably reflexive. I suggest that what is conveyed in Australia when the charge of dog whistling is levelled against members of the Coalition - and even, at times, against a Labor prime minister - is, first, an overt message that those charged are playing dirty. Secondly, a coded message is conveyed to those on the Left who can see the justice in this charge, a message that reinforces an existing sense of superiority over those who are taken in by the Coalition's, or prime minister's, dirty play. The coded message is simply that we constitute an observant, morally superior elite.

This is dog whistling without the unsavoury racism. It seems to me relatively harmless, at least in the short term. In the longer term it simply offers the Right further ammunition to use against the Left.

\section{Conclusion}

With regard to the issue of deniability, there are two basic points to be made. First, as already noted, if 'deniability' has any clear meaning, it is best seen as an attribute, not of anything that might or might not have been said, but rather of some person or organisation who might be accused of having said it. As Howard realised, all that was required for a public figure or political party to possess this attribute was the ability to issue the denial with a straight face, along with a 
reasonably compliant media that would not call him on it. Having lived through the Howard era in Australia, I suspect that many journalists (but not too many of their editors) found this compliance difficult to stomach.

As for what is required in the content of the denial, the answer was made clear by the second billboard of the British 'Are you thinking ...' campaign and, for that matter, in Gillard's response to the charge of dog whistling and xenophobia: simply repeat the offense on a highly visible billboard or with sufficient assurance. All that has to be denied is the suggestion that members of the target group have base motivations.

\section{References}

Ashcroft, M.A. 2010. Minority verdict: The Conservative Party, the voters and the 2010 election. London: Biteback.

Bagehot 2005. High pitch, low politics: Dog-whistle politics can only take you so far. Economist 23 March.

Brett, J. 2007. Robert Menzies' forgotten people. Carlton: Melbourne University Press.

Cicero, Quintus Tullius 2012. How to win an election. An ancient guide for modern politicians. Princeton: Princeton University Press.

Fear, J. 2007. Under the radar. Dog-whistle politics in Australia. Discussion paper 96. Canberra: The Australia Institute.

Freeland, J. 2005. Beware the nasty nudge and wink. Guardian 12 April.

Goodin, R.E. 2008. Innovating democracy: Democratic theory and practice after the deliberative turn. Oxford: Oxford University Press.

and Saward, M. 2005. Dog whistles and democratic mandates. The Political Quarterly 76(4): 471-76.

Hall, B. 2013. Refugees much less likely to commit crime. Sydney Morning Herald 1 March.

Hobbes, T. 1996 (1651). Leviathan. Cambridge: Cambridge University Press.

Ireland, J. 2013. Visa stand not xenophobic: Gillard. Sydney Morning Herald 7 March.

Kettle, M. 2005. The Conservative manifesto is a thing of punchlines, not programmes. Guardian 8 March. 
Lincoln, B. 2004. Words matter: How Bush speaks in religious code. Boston Globe 12 September.

McAllister, J.F.O. 2005. Whistling in the dark? Time Magazine 3 April.

Manning, P. 2004. Dog whistle politics and journalism. Sydney: The Australian Centre for Independent Journalism, UTS.

Menzies, R. 1942. The forgotten people. Liberals.Net. 22 May. URL http://www. liberals.net/theforgottenpeople.htm. Consulted 9 March 2013.

Safire, W. 2005. Dog-whistle. New York Times 24 April.

— 2008. Safire's political dictionary. New York: Oxford University Press.

Sawer, M. and Hindess, B. 2004. Us and them: Elites and anti-elitism in Australia. Perth: API Network.

Weber, M. 1989. Science as a vocation. P. Lassman, V. Irving et al. eds. London, Unwin Hyman.

Wills, Gary 2012. Review of Cicero (2012), New York Times 27 July 27. 
This text taken from Studies in Australian Political Rhetoric, Edited by John Uhr and Ryan Walter, published 2014 by ANU Press, The Australian National University, Canberra, Australia. 